\title{
THE ROLE OF GLOBAL G.A.P. IN IMPROVING COMPETITIVENESS OF AGRO-FOOD INDUSTRY
}

\author{
Cariša Bešićc , Srđan Bogetič́2, Dragan Ćoćkalo ${ }^{3}$, Dejan Dorđevićc
}

\begin{abstract}
Summary
The issues of food safety, standards and food quality represent a challenge for every food company which has to cope with in order to survive. The change in consumers attitudes has considerably been influenced by certain incidents related to food safety which clearly showed that more attention should be paid to food safety. Different actors should work together on this issue, from food producers (primary and final), consumer associations, international organizations, big retailers to the state. The purpose of this paper is to analyze the current situation in implementation of certification schemes for agro-food industry in which GLOBAL G.A.P. has been recognized as a perspective one. A special attention is paid to two directions: (1) Comparison of implementing GLOBAL G.A.P. standard and other Certification schemes and (2) Overview and opportunities for Serbia and neighboring countries, in relation to its EU food law and food safety certification schemes harmonization efforts.
\end{abstract}

Keywords: agro-food industry, certification schemes, GLOBAL G.A.P., competitiveness, Serbia.

JEL: D24, Q13, Q18.

\section{Introduction}

In recent years in developed countries a trend related to production of healthy food has

1 Cariša Bešić, Ph.D., Associate Professor, University of Kragujevac, Faculty of technical science Čačak, 32000 Čačak, Svetog Save Street no. 65, Republic of Serbia. Phone: +381 6036996 96, E-mail: carisa.besic@sbb.rs.

2 Srđan Bogetić, Ph.D., Professor, Belgrade Business School, 11000 Belgrade, Kraljice Marije Street no. 73, Republic of Serbia. Phone: +381 6412542 92, E-mail: sbogetic@yahoo.com.

3 Dragan Ćoćkalo, Ph.D., Associate Professor, University of Novi Sad, Technical faculty "Mihajlo Pupin" in Zrenjanin, 23000 Zrenjanin, Đure Đakovića Street nn., Republic of Serbia. Phone: +381 6280197 41, E-mail: cole@ttzr.uns.ac.rs.

4 Dejan Đorđević, Ph.D., Full Professor, University of Novi Sad, Technical faculty "Mihajlo Pupin" in Zrenjanin, 23000 Zrenjanin, Đure Đakovića Street nn., Republic of Serbia. Phone: +381 6280197 26, E-mail: djole@,rocketmail.com.

EP 2015 (62) 3 (583-597) 
been developed. European Union (EU) pays a great attention to safe food which can be illustrated by EU Council and Parliament Directions. In Introduction part it is written that (Varga et al., 2006) free flux of safe and healthy food is a crucial element of interior market (EU) which significantly contributes to health and welfare of the citizens as well as to social and economic interests.

Food production, distribution and consumption have a significant influence on the environment (e.g. great energy and material demand, emission of $\mathrm{CO}_{2}$ increased needs for agricultural areas), but they also have a serious social, economic and medical consequences (e.g. health risks, increased obesity, hunger). From the aspect of sustainability, there have been many changes in behavior of people in developed countries which results in increased energy consumption, agricultural areas and other resources. Therefore, the trend is being developed in those countries in relation to food consumption which can be observed through two elements: its influence on the environment and health.

However, beside consumers, food industry as well has begun changing its relationship towards food production. The reasons for such relations can be found in the following trends:

- Changes on food markets which are more and more oriented towards safe and healthy food;

- Greater role of primary food production in the process of safe food production;

- Increased care of the society related to environmental protection through reduction of pollution, energy efficiency increase and usage of alternative energy sources;

- Technological changes in food production which enable better food processing, as well as more secure and safer delivery through logistic chain;

- New legal regulations demanding production of safe and healthy food without using chemical supplements;

- Enlarging wholesale chains which results in increased competitiveness.

In Rural Development Programme from 2014 to 2020 European Union obliged all countries members to finance directly farmers with $30 \%$ of incestive funds which would be invested in implementation of sustainable agricultural methods (ecologically acceptable). It means that if you deal with environmentally friendly farming you will not have to change the way of work in order to adjust your methods to environmentally friendly ones. There is also a new support programme for the current farmers who want to move on to ecological farming (within Common Agricultural Policy - CAP). All countries members can offer incentives to environmentally friendly farmers via various types of flexible financial options which will support, for example, cooperation in food production chain for the sake of supporting innovations, development of plans related to quality of agricultural products, making groups or producers'organizations, etc. (Parađiković, 2015). 


\section{Methodology and purpose}

Implementation of standards in Agro-food industry is becoming a pre-condition for improved business. The importance of implementing standards in agriculture is increased because they give a feeling of certainty to consumers - they are sure that the food they buy is safe and healthy. Investments in standard implementation, training of employees and creation of business chain which will take care of production in food industry are becoming an important pre-condition for increasing the level of competitive advantage on the global market.

Certification schemes globally are gaining more and more importance. The most prevalent schemes in Serbia and neighboring countries are: ISO 9001, ISO 14001, GLOBAL G.A.P., ISO 22000, BRC Global Standard, Demeter, and PDO/PGI/TSG systems. The GLOBAL G.A.P. has been recognized as a perspective one in this region. With this trend in mind and to compensate for the lack of research in this area, this paper presents an overview of certification schemes in the European agriculture and food industry, especially in Serbia and neighboring countries. In addition, the paper highlights the characteristics of these schemes and concludes with the convergence trends that can be observed throughout the European Union and beyond.

\section{Main characteristics of GLOBAL G.A.P. standard implementation}

There are numerous private food standards and regulations which differ from one another according to the extent of complacency: some of them are voluntary while the others are compulsory. Another difference is in terms of their geographic area.There are also individual standards such as Nature's Choice (Tesco), Filières Qualité, Field-to-Fork and collective national and international standards, Assured Food Standards, Qualitat Sicherheit and Farm Assured British Beef and Lamb as the examples for former and International Food Standard, Marine Stewardship Council, Forest Stewardship Council and GLOBALG.A. pas the examples of the latter.

A variety of quality assurance systems have been adopted to manage particular product attributes. While each firm is unique, industries have established, over time, a similar pattern of quality assurance systems adoption and implementation - several different quality assurance systems are adopted and pieced together to obtain a satisfactory level of control for each of desirable attributes of the product. (Gawron, Theuvsen, 2009.)

The BRC Global Standard, which includes quality management system audits in food processing companies, grew out of the initiative of The British Retail Consortium - the leading trading organization in the UK. It is an international scheme with about 14.469 certificates issued in Europe and about 7.500 in the rest of the world.

Protected Designation of Origin (PDO), Protected Geographical Indication (PGI) and Traditional Specialities Guaranteed (TSG) systems started in 1992. with the support of the European Union. The main objective was to differentiate food products by guaranteeing their region-of-origin or traditional production methods. Consumers are 
informed by product labels - the focus here is on product quality. All in all (published, registered and applied), there are 1,437 PDOs, PGIs and TSGs in the European Union. (EU, 2015.)

Demeter standard, one of the first standards which started dealing with organic food,is becoming more and more important in the countries in this region, in which Slovenia and Croatia have a significant number of certified operations. Demeter has about 9,900 members in total.

ISO organization adopted the standard ISO 22000 in 2005. This standard can be implemented independently from other standardized ISO management systems. ISO 22000 integrates the principles of the Hazard Analysis and Critical Control Point (HACCP) system and application steps developed by the Codex Alimentarius Commission. By means of auditable requirements, it combines the HACCP plan with prerequisite programmes. Hazard analysis is the key to an effective food safety management system, since conducting a hazard analysis assists in organizing the knowledge required to establish an effective combination of control measures, (Surak, 2007). Complementarity with HACCP is one out of ten reasons for implementation of ISO 22000, while the other reasons are the following (Escanciano, Santos-Vijande, 2014): improve product quality and safety, improve the firm's image in the market and consumers' confidence, strengthen the firm's future competitive advantage, and improve internal processes and procedures and their monitoring. ISO 22000 is an industrial-specific risk management system for any type of food processing and marketing, which can be closely incorporated with the quality management system of ISO 9001. Combined with ISO 14001, this standard represents an equal partner in creation of integrated management system based on a risk. Although the "youngest" among a series of private standards related to food chain there is the biggest rate of growth in implementation of ISO 22000 - according to the data from 2013, this standard is implemented in 142 countries worldwide, with totally 26,847 certificate.

Positioning of GLOBAL G.A.P. in relation to some quality assurance systems is illustrated in the Table 1. 3rd party certifcation (TPC) has emerged as a signifcant regulatory mechanism in the global agro-food system - TPC reflects the growing power of supermarkets to regulate the global agro-food system (Hatanaka et al., 2005).

GLOBAL G.A.P. nowadays represents one of the most common certified schemes worldwide in the field of food industry. Initially started as EUREPG.A.P. it was turned into GLOBAL G.A.P. in 2007 as more and more producers and retailers around the globe got connected over time. Primarily a pre-farm-gate process standard, for worldwide food safety affairs GLOBAL G.A.P. has increasingly been considered as a main reference for Good Agricultural Practice (G.A.P.). In countries including Austria, Chile, Denmark, France, Germany, Japan, Kenya, Mexico, New Zealand, Spain, and the UK, the GLOBAL G.A.P. has been incorporated into their domestic G.A.P. standards, usually in the form of public-private joint ventures (Mitchell, 2008).

In a wider context Good Agricultural Practices (G.A.P.) “applies available knowledge 
to addressing environmental, economic and social sustainability for on-farm production and post-production processes resulting in safe and healthy food and non-food agricultural products" (FAO, 2003). Good agricultural practice assumes implementation of knowledge in using natural resources on sustainable principles, in a human way and along with securing economic efficiency and social stability in order to produce safe, healthy food and other agricultural products. Generic indicators and practices of G.A.P. include aspects related to (FAO, 2003): "soil and water management, crop and fodder production, crop protection, animal production and health, harvesting and on-farm processing and storage, on-farm energy and waste management, human welfare, health and safety, and wildlife and landscape". One of the greatest benefits which G.A.P. brings is that at practical level it helps in standardization of agricultural production and improvement of agricultural products'competitiveness on the global market.

Table 1. Comparison of quality assurance systems

\begin{tabular}{|l|l|l|l|l|}
\hline $\begin{array}{c}\text { Quality } \\
\text { Assurance } \\
\text { System }\end{array}$ & $\begin{array}{l}\text { Attribute } \\
\text { managed }\end{array}$ & Implementation & \multicolumn{1}{c|}{ Advantages } & \multicolumn{1}{c|}{ Disadvantages } \\
\hline ISO 9001 & Quality & Non-mandatory & $\begin{array}{l}\text { Good fondation for a } \\
\text { quality management } \\
\text { system }\end{array}$ & $\begin{array}{l}\text { Guarantee system quality } \\
\text { only (not output quality). } \\
\text { Experiance to implement. } \\
\text { To generic. }\end{array}$ \\
\hline ISO 14001 & Environment & Non-mandatory & $\begin{array}{l}\text { Good fondation for a } \\
\text { environment } \\
\text { management system }\end{array}$ & $\begin{array}{l}\text { Does not guarantee a } \\
\text { certain level of benefits. } \\
\text { Does not specify particular } \\
\text { production practices. }\end{array}$ \\
\hline ISO 22000 & Food safety & $\begin{array}{l}\text { Mandatory } \\
\text { minimum for all } \\
\text { suppliers }\end{array}$ & $\begin{array}{l}\text { Good foundation for } \\
\text { food safety management } \\
\text { system. } \\
\text { Based on HACCP }\end{array}$ & $\begin{array}{l}\text { Dificult to implement. } \\
\text { Comprehension of the } \\
\text { system. } \\
\text { Experiance to implement. }\end{array}$ \\
\hline $\begin{array}{l}\text { GLOBAL } \\
\text { G.A.P. }\end{array}$ & $\begin{array}{l}\text { Environment } \\
\text { Food safety } \\
\text { Social }\end{array}$ & $\begin{array}{l}\text { Mandatory } \\
\text { minimum for all } \\
\text { suppliers }\end{array}$ & $\begin{array}{l}\text { Objectivity (3rd party } \\
\text { audits) } \\
\text { Reduces monitoring } \\
\text { and auditing costs. } \\
\text { Specifies production } \\
\text { practices. }\end{array}$ & $\begin{array}{l}\text { Not flexible. } \\
\text { High investment and } \\
\text { running costs. }\end{array}$ \\
\hline BRC & $\begin{array}{l}\text { Food safety } \\
\text { Value } \\
\text { Organoleptic }\end{array}$ & $\begin{array}{l}\text { Mandatory } \\
\text { minimum for all } \\
\text { suppliers }\end{array}$ & $\begin{array}{l}\text { Objectivity (3rd party } \\
\text { audits) } \\
\text { Includes food safety } \\
\text { component (HACCP) }\end{array}$ & $\begin{array}{l}\text { Not as flexible as form- } \\
\text { specific quality assurance } \\
\text { system. }\end{array}$ \\
\hline
\end{tabular}

Source: Sterns et al., 2001; Bilalis et al., 2009; Cooper, Graffham, 2012.

Thanks to good results in practice in EU, EUREPG.A.P. has spread worldwide so it was named GLOBAL G.A.P. The certificate GLOBAL G.A.P. assumes except HACCP criteria, ecology standards as well for the fields on which food is produced. There is a similarity between HACCP and GLOBAL G.A.P., which is related to the existance of the so called control points within the production process in which 
certain requirements should be satisfied in order to secure a quality production and a product harmonized to standards.

The principles of GLOBAL G.A.P. are (Qualitass Education, 2009):

- Limited and controlled usage of all types of agro-chemical substances.

- Hygienic treatment during production and manipulation of agricultural products.

- Providing instructions and recording all activities along with securing traceability.

- Original rules that enable objective verification (confirmation of the procedure).

- Mutual communication and exchange of opinions among producers, sale persons and users.

- Care for the environment and sustainable development.

- Responsible conduct towards employees on the farm.

- Care for farm animal welfare.

The Certificate GLOBAL G.A.P. assumes, except HACCP criteria, ecology standards as well for the fields on which the food is produced. Three market trends have conditioned an initiative for adoption of this standard: increasing complexity of retailer supply chains, increasing the influence of business surroundings and general complexity and enlargement of market requirements, in other words, consumers (Đorđević et al., 2011).

Consciousness related to safety and quality of food is significantly increasing on consumer goods markets. In order to satisfy their requirements, consumers are demanding from retailers, especially in developed countries, implementation and respect of strict rules, standardized procedures and activities as well as certain characteristics of products. Consumers' pressure and the external image are two of the main driving forces to certification (Darnall, Edwards, 2006).

The main requirements of the final users are (Qualitass Education, 2009):

- Healthy, quality and biologically valuable food,

- Producers' responsibility towards environmental protection,

- Human relations towards employees on the farm and

- Care for animal welfare.

The result of retailers initiative is that GLOBAL G.A.P. is being spread very fast worldwide. Firms seek certification when their partners lack credible information (Masood, 2013). In this way, through a GLOBAL G.A.P. certification scheme, retailer convey quality signal to consumers. On the other hand sides of supply chain, growers participate in the certification process in order to earn market access to export market.

The magnitude of GLOBAL G.A.P. standard can be expressed by three indicators (Masood, 2013): (a) number of GLOBAL G.A.P. certificates issued; (b) number of 
producers accepted under GLOBAL G.A.P. certification process; (c) number of hectares harvested under GLOBAL G.A.P. certification.

GLOBAL G.A.P. was spreading very fast from 2005 when about 35000 firms were included in certification process until 2012 with almost four times more firms, and finally in 2015 when over 140000 firms are being certified (Figure 1). GLOBAL G.A.P. scheme has a network of 1.400 trained inspectors and audits who work for 142 accredited certified bodies whose aim is to certify 409 agricultural products in 112 countries, (GLOBAL G.A.P., 2015a). The countries, such as Chile, Italy, Kenia, Peru, South Africa, are much more covered by this standardization scheme.

Continental share of the certificate is almost unchanged, which can be seen in the Figure 2. However, new markets are more significant for the analysis, for example, Russia with its mushrooms, Greece with sea bass and bream, Netherlands with pork production.

Figure 1. Share of certified producers

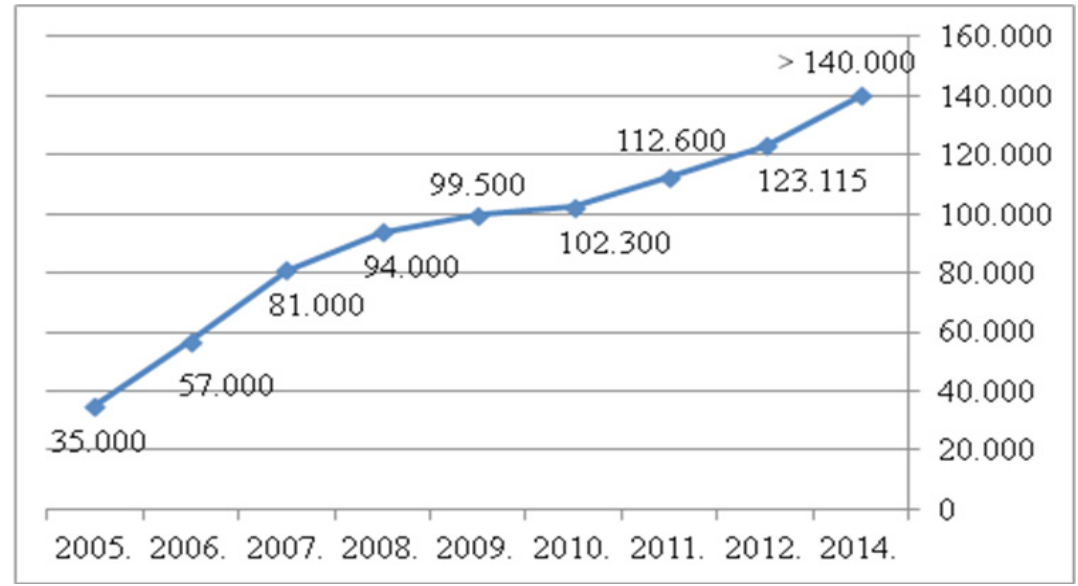

Source: GLOBAL G.A.P., 2015a. 
Figure2. Share of certified producers (in \%)

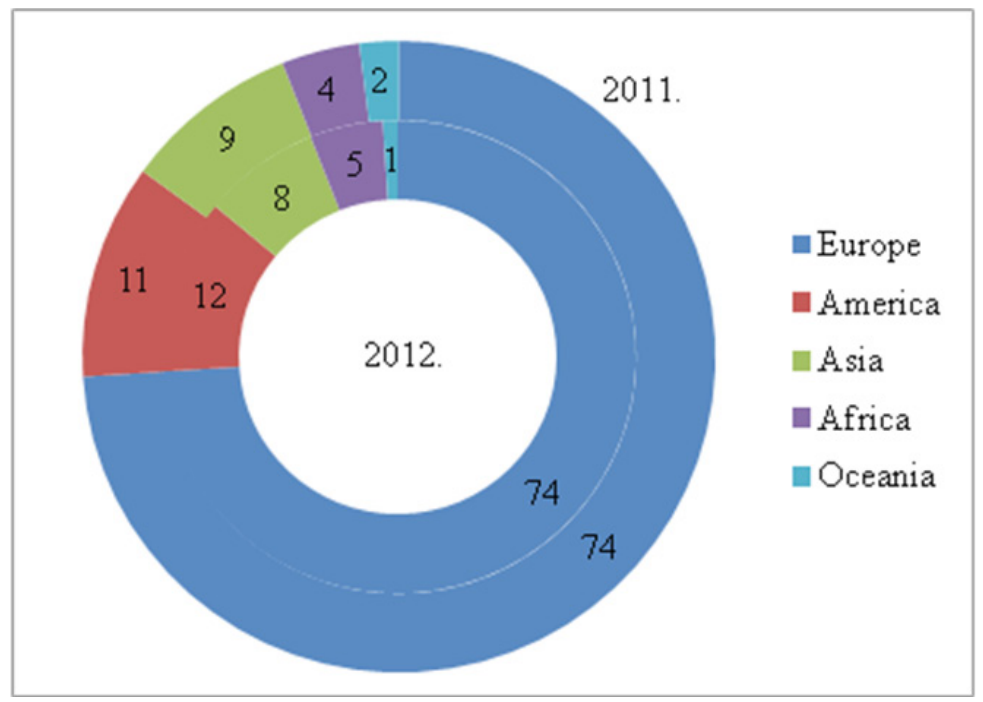

Source: GLOBAL G.A.P., 2015a.

If we look at the list of the first five countries according to the number of certified producers we'll see that these countries are, among the others, well-known for food production. It's no surprise that these countries initiated the implementation of GLOBAL G.A.P. in order to improve their competitiveness. An interesting fact is that these five countries have been on the top of the list for several years. Figure 3 shows a comparison of the leading countries related to GLOBAL G.A.P. certificates for two years successively - a significant number of certified companies in Netherlands is obvious.

Figure 3. First five countries according to the number of certified producers

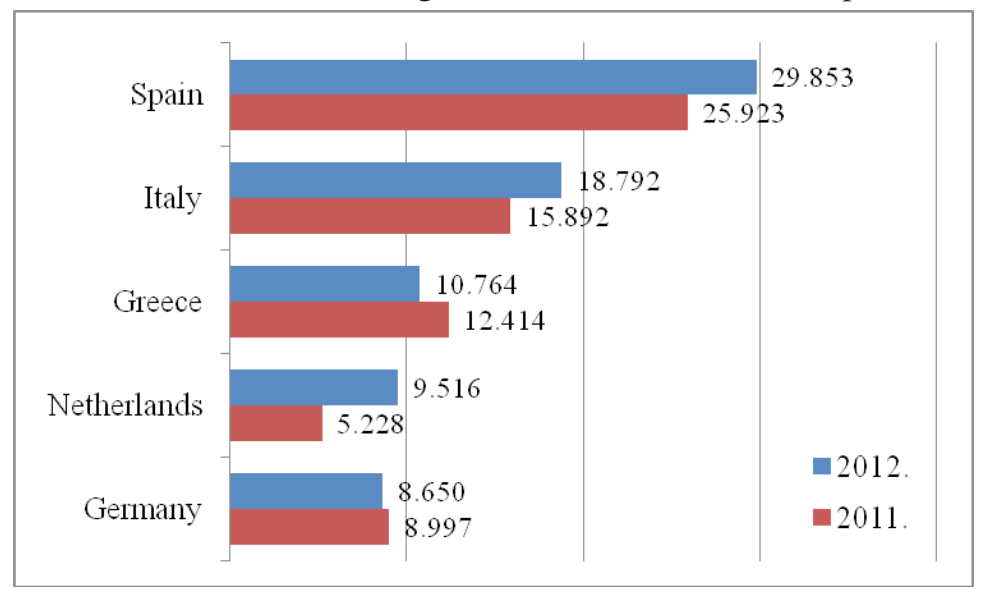

Source: GLOBAL G.A.P., 2015a. 
The acquisition of GLOBAL G.A.P. certificate assumes an obligation on the side of producers to initiate the process of registration and certification every year. There are the following four, different options of certification (Qualitass Education, 2009; GLOBAL G.A.P., 2015b):

- option 1, certification of an individual producer or a company,

- option 2, certification of a group of producers,

- option 3, parallel certification of individual producers (Benchmarking),

- option 4, parallel certification of a group of producers (Benchmarking).

Benchmarking certification is performed on an exclusive request of clients who, in that way, want to control their own equivalence via the analysis of contents and parameters in relation to GLOBAL G.A.P.

Before explaining the option 2 related to certification of a group of producers it is necessary to explain the notion of a group of producers. A group of producers represents a registered group whose aim is application for certificate acquisition. (GLOBAL G.A.P., 2015b).

A group of producers is a legally legitimate entity whose final responsibility is a production and a product. It can be registered as an association of producers, cooperations, a trade company, a warehouse and packing company, a cooperation, etc. In order to be certified under the option 2 a group of producers must have implemented QMS. All registered group members are responsible for the production of their products but they are not allowed to sell their products certified as GLOBAL G.A.P. beyond the group (Qualitass Education, 2009; GLOBAL G.A.P., 2015b).

\section{Implementation of agro-food industry standards in Serbia and neighboring countries}

The implementation of agricultural standards in Serbia still isn't adequate to the potentials of this field. Ministry of Agriculture, Forestry and Water Management of the Republic of Serbia by its Regulation on using incestive funds for introduction and certification of safety system in the period from 2005 to 2008 (Serbian Government, 2005-2008) influenced the increase of certified companies. By organizing the promotional action "Think in time" they wanted to raise consciousness on consumers' rights to this kind of protection and the importance of having a documented quality system, for food consumers. In November, 2009 Governments of Switzerland and Serbia signed the agreement on realization of the project "Aid in the field of GLOBAL G.A.P. standard".

According to the data of Ministry of Agriculture, Forestry and Water Management of the Republic of Serbia, from 2005 until the end of 2008, there were 781 certified users. In the same time, 112 of them suspended and terminated certification procedure. The greatest number of certifications but suspensions as well was in 2006-359 certifications 
and 61 suspensions (Infogo.biz, 2013). The number of certified companies is significant considering the fact that in 2004, 85\% of the companies from this industry never heard of HACCP. Connectivity of standards ISO 14001 and HACCP is highly significant for food companies. In other words, a company which implements the standard ISO 14001affects the protection of global environment (water, air, ground, natural resources, flora and fauna, people and their relations) and development of environmental quality. The standard ISO 14001has a significant activity in environmental protection, particularly in risk management. Risk management includes a decision - making in relation to the way of environmental protection activity procedure which relies on the result of risk estimation. The standard HACCP represents a management system in which safety of food products is considered through the analysis and control of biological, chemical and physical risks in complete production chain. That is the reason why HACCP represents a logical continuation of ISO 14001 in companies business.

Table 2 presents a comparative example of standards implementation in agro-food industry and their use in Serbia and neighboring countries. Regarding West Balkan countries (WBC), Serbia is a leader in relation to implementation of all schemes of standards. However, as regards to other neighboring countries Serbia lags behind significantly. Apart from GLOBAL G.A.P. implementation of other standards in Serbia is low. Comparing to Hungary, for example, Serbia lags behind considerably in implementation of GLOBAL G.A.P. scheme. This additionaly contributes to uncompetitiveness of Serbian companies. It is obvious from the Table 4 that some neighborin countries, such as Romania and Bulgaria, are more oriented towards ISO certification schemes (generally) than towards GLOBAL G.A.P. scheme, while for Serbia (strictly for food safety) the opposite is true.

There are several reasons for insufficient use of the standards in Serbian agro-food industry and they can be found in the following fact - a company which implements GLOBAL G.A.P. standard has an obligation to perform re-certification every year, which represents a significant financial effort for the company. Moreover, Ministry of Agriculture, Forestry and Water Management of the Republic of Serbia terminated cofinancing during implementation process of international standards.

Table 2. Implementation of standards in Serbia and neighboring countries

\begin{tabular}{|l|c|c|c|c|c|c|c|}
\hline & $\begin{array}{c}\text { ISO } \\
\mathbf{9 0 0 1}\end{array}$ & $\begin{array}{c}\text { ISO } \\
\mathbf{1 4 0 0 1}\end{array}$ & $\begin{array}{c}\text { ISO } \\
\mathbf{2 2 0 0 0}\end{array}$ & $\begin{array}{c}\text { GLOBAL } \\
\text { G.A.P. }\end{array}$ & BRC & $\begin{array}{c}\text { PDO/ } \\
\text { PGI/TSG }\end{array}$ & Demeter \\
\hline Albania & 167 & 34 & 7 & 0 & 1 & 0 & 0 \\
\hline $\begin{array}{l}\text { Bosnia and } \\
\text { Hercegovina }\end{array}$ & 794 & 141 & 17 & 269 & 2 & 0 & 0 \\
\hline Croatia & 2,636 & 828 & 97 & 141 & 14 & 13 & 1 \\
\hline Macedonia & 399 & 131 & 25 & 14 & 1 & 0 & 0 \\
\hline Montenegro & 118 & 24 & 7 & 0 & 0 & 0 & 0 \\
\hline Serbia & 2,366 & 762 & 193 & 281 & 37 & 0 & 0 \\
\hline Slovenia & 1,993 & 468 & 19 & 22 & 9 & 25 & 27 \\
\hline WBC Total & $\mathbf{8 , 4 7 3}$ & $\mathbf{2 , 3 8 8}$ & $\mathbf{3 6 5}$ & $\mathbf{7 2 7}$ & $\mathbf{6 4}$ & $\mathbf{3 8}$ & $\mathbf{2 8}$ \\
\hline
\end{tabular}




\begin{tabular}{|l|c|c|c|c|c|c|c|}
\hline & $\begin{array}{c}\text { ISO } \\
\mathbf{9 0 0 1}\end{array}$ & $\begin{array}{c}\text { ISO } \\
\mathbf{1 4 0 0 1}\end{array}$ & $\begin{array}{c}\text { ISO } \\
\mathbf{2 2 0 0 0}\end{array}$ & $\begin{array}{c}\text { GLOBAL } \\
\text { G.A.P. }\end{array}$ & BRC & $\begin{array}{c}\text { PDO/ } \\
\text { PGI/TSG }\end{array}$ & Demeter \\
\hline Bulgaria & 5,378 & 1,373 & 244 & 17 & 29 & 7 & 2 \\
\hline Hungary & 7,186 & 1,955 & 137 & 957 & 121 & 15 & 19 \\
\hline Romania & 18,450 & 8,744 & 1,014 & 46 & 51 & 4 & 1 \\
\hline
\end{tabular}

Source: ISO, 2014; BRC, 2015; EU, 2015; DI, 2015, GLOBAL G.A.P., 2012.

According to Đekić et al., (2011) and Smigić et al., (2015) in some Western Balkans countries (Serbia, Bosnia and Herzegovina and Macedonia) implementation of different quality and food safety assurance schemes is either required by law or large multinationals (both producers and retailers) which establish their own schemes and requirements (such as HACCP). However, other private and food quality standards are applied periodically although their implementation and certification is promoted by the governments of these countries. Except HACCP, food safety standard ISO 22000 and ISO 9001 are most commonly implemented in West Balkan countries. It should be mentioned that food producers in these countries received financial support from different governmental and nongovernmental organizations (USAid, SIEPA and EU funds). Besides HACCP, the most common certifications in the Western Balkan food industry cover food safety (ISO 22000) and quality management systems (ISO 9001).

Implementation of GLOBAL G.A.P. and other standards which are used by Serbian agrofood producers implies a support of the Government which has to create a stimulative ambience for procuders. The Government has already stimulated and supported the implementation of HACCP which is nowadays compulsory but it is also necessary to do the same with other standards in this field. At this pont it should be emphasized that food safety system in Serbia needs certain improvements related to food safety control, inspection, knowledge and expertize. In other words, there is room for improving professionals, such as inspectors, governmental officials, consultants and auditors. In addition, a lot of work and efforts should be invested in improving transparency and communication between legal authorities, consumers and food business operators, (Smigić et al., 2015). Moreover, it is necessary to re-establish supporting mechanisms to Serbian agro-food producers through the support in the following fields: finances, education, applying practical experiences, information on other standards close to this field, information on new trends in agricultural industry, taking part in competitions such as G.A.P. Awards.

\section{Conclusion}

The implementation of GLOBAL G.A.P in agro-food industry is of great importance both for the company which has implemented it and for other factors on the market, for example, consumers of its products, the environment in which it operates, business partners who must have the same standards as a precondition for cooperation. This is how a chain of good practice is made which motivates other companies to start the implementation of GLOBAL G.A.P. in order to assure consumers in safety of agricultural products which they buy in retail shops. 
The role of retail shops is crucial in encouraging the implementation of GLOBAL G.A.P and other standards familiar with this field. The reason lies in the fact that retailers are the first who can notice consumers' attitudes towards food. Today, consumers are well-informed about healthy food as well as about new trends in this field (e.g. less fats, sugar, etc.), along with the support of international organizations (FAO) which additionally influences flexibility of producers and retailer chains.

Unfortunately, food companies in Serbia are not sufficiently supported by the state to implement GLOBAL G.A.P. We have noticed only the examples of individual support by international organizations (USAid, SIEPA, EU funds, SECO) and NGO sector so far, which is not enough if we want to make a step forward in this field.

Very implementation of GLOBAL G.A.P. has considerable advantages of which the following are identified: easier access to consumers on international markets, higher market price of products (perhaps, not in the beginning but in the future it is expected), etc. However, whether GLOBAL G.A.P. will be implemented depends only on agrofood producers and manufacturers, on their estimation and plans in relation to their company in the future. In what extent and in what way will the pressure imposed by markets, the leading commercial chains and the necessity of Serbia to turn towards competitive export of agro-food products influence Serbian agro-food industry? This question will be answered by some future researches and analysis.

\section{References}

1. Bilalis, D., Stathis, I., Konstantas, A., Patsiali, S. (2009): Comparison between HACCP and ISO 22000 in Greek organic food sector, Journal of Food, Agriculture and Environment, vol. 7, no. 2, pp. 237-242, WFL Publisher.

2. BRC (2015): BRC Directory, (available at: http://www.brcdirectory.com).

3. Cooper, J., Graffham, A. (2012): Complying with the private trade standards required to export fresh produce to Europe: Challenges for smallholder farmers, Food Chain, vol. 2, no. 1, pp. 15-23, Practical Action Publishing.

4. Darnall, N., Edwards, D. J. (2006): Predicting the cost of environmental management system adoption: the role of capabilities, resources and ownership structure, Strategic Management Journal, Wiley-Blackwell, vol. 27, no. 4, pp. 301-320.

5. DI (2015): Certified Operations in Member Countries of Demeter-International (DI), 05/2014, (available at: http://www.demeter.net/sites/default/files/DIStatistic-05-2014.pdf).

6. Đekić, I., Tomašević, I., Radovanović, R. (2011): Quality and food safety issues revealed in certified food companies in three Western Balkans countries, Food Control, Elsevier, vol. 22, no. 11, pp. 1736-1741.

7. Đorđević, D., Ćoćkalo, D., Bogetić, S. (2011): An analysis of the HACCP system implementation - The factor of improving competitiveness in Serbian companies, 
African Journal of Agricultural Research, Academic Journals, vol. 6, no. 3, pp. 515-520.

8. Escanciano, C., Santos-Vijande, M. L. (2014): Reasons and constraints to implementing an ISO 22000 food safety management system: Evidence from Spain, Food Control, Elsevier, vol. 40, pp. 50-57.

9. EU (2015): DOOR database ("Database of Origin and Registration"), (available at: http://ec.europa.eu/agriculture/quality/schemes/index en.htm).

10.FAO (2003): Development of a Framework for Good Agricultural Practices, Committee on Agriculture, Seventeenth Session, 31 March-4 April 2003, Rome, FAO, (available at: ftp://ftp.fao.org/docrep/fao/meeting/006/y8704e.pdf).

11.Gawron, J.C., Theuvsen, L. (2009): Certification schemes in the European agrifood sector: Overview and opportunities for Central and Eastern Europe, Outlook on Agriculture, IP Publishing, vol. 38, no. 1, pp. 9-14.

12.GLOBAL G.A.P. (2012): GLOBAL G.A.P. Fruit \& Vegetables, (available at: http://www.globalgap.org/export/sites/default/.content/.galleries/ documents/120813-InfoKIT FV web en.pdf).

13.GLOBAL G.A.P. (2015a): Facts and figures, available at: www.globalgap.org

14.GLOBAL G.A.P. (2015b): Standards - Certification and Assessment Options, (available at: http://www1.globalgap.org/north-america/front_content. php?idcat=263).

15.Hatanaka, M., Bain, C., Busc, L. (2005): Third-party certification in the global agrifood system, Food policy, Elsevier, vol. 30, no. 3, pp. 354-369.

16.Infogo.biz (2013). GLOBAL G.A.P. u srpskoj poljoprivredi, (available at: http:// www.infogo.biz/global-gap-u-srpskoj-poljoprivredi.html).

17.ISO (2014): The ISO Survey 2013, (available at: http://www.iso.org/iso/isosurvey_2013.zip ).

18.Masood, A. (2013): Geographic variation in global diffusion of private food standards: The case of GlobalGAP certification, F.R.E.I.T. Working Paper No. 649, (available at: http://www.freit.org/WorkingPapers/Papers/TradePatterns/ FREIT649.pdf ).

19. Mitchell, L. (2008): Private standards and international trade, IATRC January Meeting. Washington DC, USA.

20.Parađiković, I. (2015): Veći podsticaji iz EU članicama, (available at: http:// agroinfotel.net/index.php?option $=$ com_content\&view $=$ article \&id=5733:veipodsticaji-iz-eu-lanicama\&catid=12:agroekonomija\&Itemid=34 ).

21.Qualitass Education (2009): GLOBAL G.A.P. - Korak ka globalnom tržištu, Qualitass Education, USAID Agrobusiness project, Kragujevac.

22.Serbian Government (2005-2008): Uredba o korišćenju podsticajnih sredstava za uvođenje i sertifikaciju sistema bezbednosti hrane, Vlada Republike Srbije, 
Beograd.

23.Smigić, N., Rajković, A., Đekić, I., Tomić, N. (2015): Legislation, standards and diagnostics as a backbone of food safety assurance in Serbia, British Food Journal, Emerald, vol. 117, no. 1, pp. 94 - 108.

24.Sterns, P. A., Codron, J. M., Reardon, T. (2001): Quality and quality assurance in the fresh produce sector: a case study of European retailers [Selected Paper], 2001 Annual meeting, August 5-8, Chicago, IL, American Agricultural Economics Association.

25.Surak, J. G. (2007), A Recipe for Safe Food: ISO 22000 and HACCP, Quality Progress, ASQ, vol. 40, no. 10, pp. 21-27.

26.Varga, J., Đorđević, L., Đorđević, B., Karadžić, M., Nemet, B., Darvaš, O., Ulična, E. (2006): HACCP $i$ bezbednost hrane, Novi Sad: Adižes. 


\title{
ULOGA GLOBAL G.A.P.-A U UNAPREĐENJU KONKURENTNOSTI POLJOPRIVREDNO-PREHRAMBENE INDUSTRIJE
}

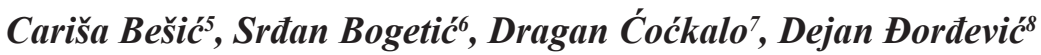

\begin{abstract}
Apstrakt
Pitanja bezbednosti hrane, standardizacije i kvaliteta hrane, predstavljaju izazove za svako preduzeće u ovoj oblasti, na koje ono mora da odgovori ukoliko želi da opstane na tržištu. Na promenu stavova potrošača, značajno su uticali određeni incidenti sa bezbednošću hrane, koji su pokazali da se pitanju bezbednosti hrane mora posvetiti posebna pažnja. U ovom lancu moraju zajedno biti uključeni različiti akteri, od proizvođača hrane (primarni i finalni), udruženja potrošača, međunarodnih organizacija, velikih maloprodajnih lanaca do države. Cilj ovog rada je da se analizira trenutna situacija u primeni sertifikacionih šema u poljoprivredno-prehrambenoj industriji, gde je GLOBAL G.A.P. prepoznat kao perspektivan. Posebna pažnja je upućena u dva pravca: (1) Komparacija primene GLOBAL G.A.P. standarda u odnosu na druge sertifikacione šeme i (2) Pregled i mogućnosti za Srbiju i susedne zemlje, u odnosu napore koji se ulažu $u$ harmonizaciju zakona i šema sertifikacije sa onima koji su zastupljeni $u$ EU.
\end{abstract}

Ključne reči: poljoprivredno-prehrambena industrija, sertifikacione šeme, GLOBAL G.A.P., konkurentnost, Srbija.

5 Vanredni profesor, dr Cariša Bešić, Univerzitet u Kragujevcu, Fakultet tehničkih nauka, Čačak, 32000 Čačak, Svetog Save 65, Republika Srbija. Telefon: +381 603699696 , E-mail: carisa.besic@,sbb.rs

6 Redovni profesor, dr Srđan Bogetić, Beogradska Poslovna Škola, 11000 Beograd, 73 Kraljice Marije, Republika Srbija.Telefon: +381 6412542 92, E-mail: sbogetic@yahoo.com

7 Vanredni profesor, dr Dragan Ćoćkalo, Univerzitet u Novom Sadu, Tehnički fakultet "Mihajlo Pupin" u Zrenjaninu, 23000 Zrenjanin, Đure Đakovića bb, Republika Srbija. Telefon: +381 6280197 41, E-mail: cole@,tfzr.uns.ac.rs

8 Redovni profesor, dr Dejan Đorđević, Univerzitet u Novom Sadu, Tehnički fakultet "Mihajlo Pupin" u Zrenjaninu, 23000 Zrenjanin, Đure Đakovića bb, Republika Srbija. Telefon: +381 6280197 26, E-mail: djole@,rocketmail.com

EP 2015 (62) 3 (583-597) 